\title{
A review on biological activities of Gelam honey
}

\author{
Syed Ahmad Tajudin Tuan Johari ${ }^{1,2 *}$, Fatimah Hashim¹, Wan Iryani Wan Ismail ${ }^{1}$, Abdul Manaf Ali ${ }^{2}$ \\ ${ }^{1}$ School of Fundamental Science, Universiti Malaysia Terengganu, 21030 Kuala Terengganu, Malaysia, ${ }^{2}$ Department of Agriculture Science and Biotechnology, \\ Faculty of Bioresources and Food Industry, Universiti Sultan Zainal Abidin, 22200 Besut, Terengganu Darul Iman, Malaysia
}

\begin{tabular}{l}
\hline ARTICLE INFO \\
\hline Article history: \\
Received on: April 04, 2018 \\
Accepted on: April 27, 2018 \\
Available online: January 20, 2019 \\
\hline Key words: \\
Honey, \\
Biological activities, \\
Gelam honey
\end{tabular}

\begin{abstract}
Honey has been extensively researched on their chemical and biological properties. It's revealed the ability and capability of honey in treating or preventing many diseases. As people concerned, a safer approach using natural based product is critically needed and honey as one of the potential agent to be consider. Therefore, the information on its biological activities has to be clarify to make society understand the benefit of honey especially Gelam honey.
\end{abstract}

\section{INTRODUCTION}

The use of natural sources in treating cancer becomes more visible nowadays. Promising data from research revealed its biological activities especially on human health. Honey is one of the potential candidates. Honey has been consumed since ancient time. Variety of sugars, flavonoids, phenolic acids, enzymes, amino acids, proteins, and other compounds can be found in honey $[1,2]$. The composition of honey usually depends on the flowers consumed by honey bees and environmental factors. Thus, the main focused in this review is on Gelam honey which was harvested from Gelam forest. Gelam honey mostly origin from Terengganu, Malaysia as it has plentifully of Gelam forest [3]. The Gelam or Melaleuca is a member of the Myrtaceae family with reported to have the properties such as antiinflammatory [4], anticancer [5], hepatoprotective [6], and anthelmintic activities [7]. Therefore, the reviews on scientific studies were needed on the biological activities of Gelam honey, which later can be used in the development of alternative natural-based therapy drugs.

\section{GELAM HONEY AS AN ANTIMICROBIAL}

Honey is well established for its potent antimicrobial activity against numerous types of bacteria. These include Acinetobacter baumannii, Enterobacter aerogenes, vancomycin-resistant Enterococcus faecium, cotrimoxazole-resistant Escherichia coli, Haemophilus influenzae, Klebsiella oxytoca, Klebsiella pneumoniae, ciprofloxacin-resistant Pseudomonas aeruginosa, Salmonella sp. (S. california, S. enteridis,

\section{*Corresponding Author:}

Syed Ahmad Tajudin Tuan Johari, School of Fundamental Science, Universiti Malaysia Terengganu, 21030 Kuala Terengganu, Malaysia.

E-mail: syedtajudin85@gmail.com and S. typhimurium), methicillin-resistant Staphylococcus aureus (MRSA), and a number of multidrug-resistant bacterial isolates [8]. Factors such as acidity levels (low $\mathrm{pH}$ ), osmotic pressure, hydrogen peroxide $\left(\mathrm{H}_{2} \mathrm{O}_{2}\right)$ content as well as the presence of non-peroxide components, for example, methylglyoxal might contribute to this effect. In addition, varying degrees of antimicrobial properties of honey also have been attributed to geographical disparities, floral sources and the concentration of honey used in certain treatments [9]. With regards to Gelam honey, several studies have been performed to evaluate its antimicrobial effect against selected bacterial strains.

Zainol [10] performed a comparative study of the antibacterial activity of Gelam honey besides other Malaysian honeys (acacia, Kelulut, pineapple, and Tualang) against $S$. aureus, Bacillus cereus, E. coli, and $P$. aeruginosa. Analysis of results showed that Gelam honey had the lowest minimum inhibitory concentration (MIC) and minimum bactericidal concentration (MBC) values, at 5\%(w/v) and $6.25 \%$ $(\mathrm{w} / \mathrm{v})$, respectively, against $S$. aureus compared with other bacterial isolates. Pineapple honey, on the other hand, was required at a highest concentration to inhibit and eliminate $E$. coli and $P$. aeruginosa with the MIC and MBC values at 25\% (w/v) and 50\% (w/v), respectively. In the agar inhibition assay, Gelam honey demonstrated highest antibacterial activity against $B$. cereus with 23.04 equivalent phenol concentrations (EPC) and non-peroxide activity of 22.31 EPC. Besides, acacia honey has been shown to possess lowest antibacterial activity against $E$. coli with a total EPC activity and non-peroxide EPC activity of 7.85 and 7.59 , respectively. Taken together, results from this study imply that bacterial elimination by honey occurred at a concentration-dependent and microbial-dependent manners in which Gelam honey was found to be a potent antibacterial agent against $S$. aureus and B. cereus [10]. Both $S$. aureus and B. cereus are among the 
major pathogenic bacteria which can cause various life-threatening infections in human $[11,12]$.

In the following study, Gelam, Tualang, and Durian honeys were tested for their growth inhibitory activities against $S$. aureus, S. epidermidis, E. coli, Salmonella enterica serovar Typhimurium, K. pneumoniae, and vancomycin-resistant enterococci (E. faecium and E. faecalis). It was demonstrated by the results that Gelam honey had superior inhibitory activity compared to Tualang honey at the concentration started from $40 \% \mathrm{v} / \mathrm{v}$ of undiluted honey. It was effective against all tested bacteria with the MIC and MBC values ranging from $125-1000 \mathrm{mg} / \mathrm{mL}$ to $125-2000 \mathrm{mg} / \mathrm{mL}$, respectively. Moreover, Durian honey exhibited the weakest antibacterial effect and therefore ranked third compared to Tualang and Gelam honey at the second and first position, respectively, for their potency as antibacterial agent [13]. In a recent study, $\mathrm{Ng}$ and partner tested the anti-staphylococcal effect of Gelam honey using $S$. aureus methicillin-sensitive (MSSA) and methicillin resistant (MRSA) strains. Based on the results, they found that Gelam honey at $80 \%(\mathrm{v} / \mathrm{v})$ exerted highest bacterial growth inhibition in both strains, nearly similar to that of undiluted honey. The effect was speculated to be due to the high viscosity of honey which controls the diffusion of bactericidal substances [14]. Biofilm is characterized by the existence of a population of cells that attach irreversibly on numerous biotic and abiotic surfaces and enclosed in a hydrated matrix of exopolymeric substances, proteins, polysaccharides, and nucleic acids [15]. Biofilm has been implicated with $80 \%$ of human bacterial infections, which, causes the infected area resistant to antimicrobial agents [16]. Enterococci, particularly E. faecium and E. faecalis have been identified as the third major cause of nosocomial infection generally by the use of indwelling medical devices including (central) venous and urinary catheters [17]. Honey has been suggested as an effective agent to reduce biofilm formation by pathogenic bacteria such as E. coli O157:H7 [18]. Previous study compared the effectiveness of Gelam honey along with Manuka honey in the reduction of established biofilm mass and inhibition of biofilm formation produced by E. faecium and E. faecalis. According to the results, although Manuka honey was found to be more superior to Gelam honey in terms of reducing the established biofilm mass in most of the bacterial strains, the effect was comparable in both honeys for their ability to prevent the biofilm formation. Overall, this study suggested the potential use of Gelam honey as biofilm inhibiting agent in the hospital or other health-care facilities to reduce the risk of contamination by an infectious agent which, pose hazardous effects to patients [19].

Another study by Aljadi [20] focused on the effect of phenolic extracts derived from Gelam and coconut honey on E. coli and MSSA and MRSA strains. Results in the broth dilution assay indicated that phenolic extract of Gelam honey at $1.3 \mathrm{mg} / \mathrm{mL}$ concentration partially inhibited the growth of all bacterial strains, and all bacteria were found to be completely inhibited at $\geq 1.95 \mathrm{mg} / \mathrm{mL}$ concentration. Contrary to these results, phenolic extract of coconut honey failed to demonstrate the similar effect at $1.3 \mathrm{mg} / \mathrm{mL}$ concentration. Nevertheless, the extract partially inhibited the growth of $S$. aureus and MSSA at $1.95 \mathrm{mg} / \mathrm{mL}$ concentration, and complete inhibition of all bacterial strains was demonstrated at $\geq 2.6 \mathrm{mg} / \mathrm{mL}$. Subsequent analysis using disk-diffusion assay showed that Gelam honey extract successfully inhibited all tested bacterial strains in a dose-dependent manner at the point of its lowest $(0.65 \mathrm{mg})$ to the highest $(3.25 \mathrm{mg})$ concentrations. They further postulated that these disparate antimicrobial properties of Gelam and coconut honey were attributed to the presence of phenolic contents; Gelam honey had higher phenolics (benzoic acid, gallic acid, cinnamic acid, caffeic acid, and ferulic acid) than that of coconut honey extract (benzoic acid, gallic acid, and caffeic acid). Therefore, it is not surprising that the effects are more pronounced in Gelam honey compared to coconut honey [20].

\section{GELAM HONEY AS AN ANTI-CANCER}

Common treatment modalities for cancer using chemotherapy and radiotherapy sometimes pose an adverse effect on patients as they can be lethal to other viable cells in the body [21]. Therefore, shifting paradigm toward the use of natural products as an alternative treatment has attracted a great deal of research interest these years [21,22]. Honey is among the natural product which is actively researched in multiple studies for its anticancer properties. The mechanisms by which honey exerted its anticancer effects are generally through its ability to induce apoptosis through up-regulation of pro-apoptotic proteins (p53, Bax, caspase 3, and caspase 9) and downregulation of anti-apoptotic protein Bcl-2 besides inhibiting the proliferative capacity of cancerous cells [21]. A number of previous studies have suggested that Gelam honey possess anti-proliferative capacity against cancer cell lines. In 2011, Abu and colleagues tested the antiproliferative capacity of Gelam honey against several human cancer cell lines (breast adenocarcinoma, MCF-7; colorectal carcinoma, HCT116; alveolar basal epithelial adenocarcinoma, A549 and hepatocellular, HepG2). Results showed that Gelam honey exerted its anti-proliferative effect and induce cell death in all tested cancer cell lines in a time- and dose-dependent manner when there was a significant reduction in the growth of HCT116 cell line at 24, 48, and $72 \mathrm{~h}$ with the $\mathrm{IC}_{50}$ values of $15.30,4.31$, and $3.98 \%(\mathrm{v} / \mathrm{v})$, respectively. Therefore, the maximum cytotoxic effect was achieved at $72 \mathrm{~h}$ at a concentration of $3.98 \%(\mathrm{v} / \mathrm{v})$. In a similar fashion, Gelam honey exhibited maximum cytotoxic effect against MCF-7 at $72 \mathrm{~h}$ with $\mathrm{IC}_{50}$ value of $6.31 \%(\mathrm{v} / \mathrm{v})$, suggesting its potential as a chemopreventive agent against cancer [23].

Furthermore, Jubri [24] investigated the anti-proliferative effects of Gelam honey on liver cancer (HepG2) and normal liver (WRL-68) cell lines. It has been found that Gelam honey exhibited anti-proliferative capacity against both cell lines in a dose-dependent manner with the $\mathrm{IC}_{50}$ values of $25 \%$ and $70 \%$, respectively, for HepG2 and WRL68 cells. Further analysis using bromodeoxyuridine assay revealed that Gelam honey resulted in the decrease in HepG2 cell proliferation at $3-70 \%$ concentrations. Moreover, they found that HepG2 cells treated with Gelam honey at $\mathrm{IC}_{50}$ dose of $25 \%$ following $48 \mathrm{~h}$ incubation displayed cellular shrinkage thereby supporting the effectiveness of Gelam honey as the anti-proliferative agent through its ability to induce apoptosis [24]. In another study, Fadhli [25] studied the antiproliferative effect of Gelam honey on colon cancer (HCT116) cell line. Analysis revealed that Gelam honey exerted its suppressive effect on the cell proliferation in both time- and dose-dependent manner with the $\mathrm{IC}_{50}$ values of $2.1,4.4$, and $2.0 \%$, respectively, recorded at 24,48 , and $72 \mathrm{~h}$. Therefore, they concluded that Gelam honey at $\mathrm{IC}_{50}$ value at $2.0 \%(\mathrm{v} / \mathrm{v})$ concentration for $72 \mathrm{~h}$ treatment was considered as effective to inhibit the proliferation of cancerous cells, particularly in the cancer of colon. In addition to that, they further speculated that the presence of phenolic content at high concentration took part in facilitating cancer cell deaths [25]. Apart from that, a group of researchers from Universiti Kebangsaan Malaysia, Kuala Lumpur performed a comparative study of the anti-proliferative effects of Gelam and Nenas honey on colon cancer (HT29) cell line. They analyzed the cancer cells using the 3-(4,5-dimethylthiazol-2-yl)-5-(3-carboxymethoxyphenyl)2-(4-sulfophenyl)-2H-tetrazolium (MTS) assay after incubating the 
cells with Gelam and Nenas honey at varying concentrations from 0 to $150 \mathrm{mg} / \mathrm{mL}$. Gelam honey was demonstrated to be more superior than that of Nenas honey in the suppression of colon cancer cell with the $\mathrm{IC}_{50}$ values of $39.0 \mathrm{mg} / \mathrm{mL}$ and $85.5 \mathrm{mg} / \mathrm{mL}$, respectively. Results also indicated that colon cancer cells treated with Gelam honey at its $\mathrm{IC}_{50}$ concentration led to increased total DNA damage and percentage of apoptotic cells compared to control [26].

There is emerging evidence highlighting the importance of combining specific dietary phytochemicals which might confer protective advantage against cancer compared to independent compounds [27]. Therefore, several studies took initiatives to perform a combination treatment of Gelam honey along with other natural sources to see whether they can act synergistically to inhibit the growth of cancer cells or not. Hakim [28] performed a study with the primary objective to assess the effectiveness of combination treatment between Gelam honey and ginger extract in augmenting the impact of 5-fluorouracil (5-FU) on colorectal cancer (HCT116) cell growth inhibition and apoptosis. 5-FU is one of the most frequently used chemotherapeutic agents to treat a broad range of cancers including colorectal cancer. The mechanism by which this drug exhibited its anticancer effects is through the inhibition of thymidylate synthase and incorporation of its antimetabolites into RNA and DNA [29]. According to Hakim [28], initial treatment with ginger extract alone or Gelam honey showed a remarkably different anti-proliferative capacity between these two compounds. Ginger extract exhibited a superior anti-proliferative capacity against colorectal cancer cells with an $\mathrm{IC}_{50}$ value of $3 \mathrm{mg} / \mathrm{mL}$ compared to Gelam honey at $75 \mathrm{mg} / \mathrm{mL}$. Subsequent experiment by combining $2 \mathrm{mg} / \mathrm{mL}$ of ginger extract with Gelam honey successfully inhibited the growth of cancer cells with an $\mathrm{IC}_{50}$ value of Gelam honey $<30 \mathrm{mg} / \mathrm{mL}$, lower than that of single treatment with Gelam honey alone $(75 \mathrm{mg} / \mathrm{mL})$. Moreover, the combination index $(\mathrm{CI})$ at 0.960 which is lower than 1 indicates the synergism between these compounds. Apart from that, they found that cotreatment effect between ginger extract and Gelam honey with 5 -FU resulted in significant reduction of cell growth by $72 \%, 75 \%$, and $80 \%, 3$ times higher than the treatment with 5-FU alone, suggesting that these compounds further enhance the effect of 5-FU in suppressing the growth of cancer cells. In the following analysis, it was found that Gelam honey and ginger extract interacts with each other in a dosedependent manner at a combination dose of $32 \mathrm{mg} / \mathrm{ml}$ and $2 \mathrm{mg} / \mathrm{mL}$, respectively, to induce the apoptotic activity of colorectal cancer cells. Therefore, they suggested that combined treatment with these natural compounds had the potential to increase the chemotherapeutic effect of 5-FU against this cancer [28].

Despite these promising results, the signaling pathway mechanisms involved in the chemotherapeutic effect of Gelam honey combined with ginger extract remains to be elucidated. Thus, a few studies have been undertaken with the purpose of unraveling the anticancer mechanisms involved during the combination of these compounds. In a previous study of Tahir [30], the potential interactions between crude ginger extract and Gelam honey to inhibit the growth of colorectal cancer (HT29) cell line have been investigated. The experiments were conducted by treating colorectal cancer cells with an independent and combination treatment between ginger extract and Gelam honey using a range of honey concentrations $(1-70 \mathrm{mg} / \mathrm{mL})$ and fixed concentrations of ginger extract at 2,3, or $4 \mathrm{mg} / \mathrm{mL}$. Results of MTS assay had suggested the synergistic interactions of both compounds when the $\mathrm{IC}_{50}$ values of the combination treatments between ginger extract $(3 \mathrm{mg} / \mathrm{mL})$ plus Gelam honey $(27 \mathrm{mg} / \mathrm{mL})$ with a CI of $<1$
( $\mathrm{CI}=1,>1$, and $<1$ denotes additivity, antagonism, and synergism, respectively) were found to be lower than that of independent treatment with ginger and Gelam honey at $5.2 \mathrm{mg} / \mathrm{mL}$ and $80 \mathrm{mg} /$ $\mathrm{mL}$, respectively. Moreover, both compounds have been shown to work synergistically to induce early apoptosis through an increase in the expression of caspase 9 and I $\mathrm{B}$ genes followed by underexpression of KRAS, ERK, AKT, Bcl-xL, and NFאB (p65) genes. Overall, study findings imply that amalgamation of ginger extract with Gelam honey is highly effective to enhance the cytotoxic activity and repress the growth of cancer cells by modulating the KRAS/ERK/PI3K/AKT pathways, therefore, holds great potential to be used as a colorectal chemopreventive agent in the future [30].

Another study made attempts to explore the synergistic effects of Gelam honey and ginger extract on colon cancer (HCT116) cells through mTOR, Wnt/ $\beta$-catenin and apoptosis signaling pathways [31]. The mammalian target of rapamycin (mTOR) and Wnt/ $\beta$-catenin pathways is interconnected in the multistep processes of colorectal carcinogenesis [32,33]. It was shown by the results that independent treatment with Gelam honey and ginger extract led to the decrease in cancer cell viability in a dose-dependent manner with the $\mathrm{IC}_{50}$ values of $88 \mathrm{mg} / \mathrm{mL}$ and $2.15 \mathrm{mg} / \mathrm{mL}$, respectively. On the other hand, combined treatment with $2 \mathrm{mg} / \mathrm{mL}$ ginger extract resulted in the growth inhibition of most cancer cells with an $\mathrm{IC}_{50}$ value of Gelam honey at $31 \mathrm{mg} / \mathrm{mL}$, significantly lower than single treatment with Gelam honey alone $(88 \mathrm{mg} / \mathrm{mL})$. Their works further showed that combined treatment works synergistically to reduce the expression of Akt, mTOR, Raptor, Rictor, $\beta$-catenin, Gsk $3 \beta$, Tcf4, and cyclin D1 genes while cytochrome $\mathrm{C}$ and caspase 3 genes were up-regulated. Thus, they postulated that the strategy to combine both natural compounds holds great potential as chemopreventive agent against colorectal cancer through inhibition of these signaling pathways [31].

\section{GELAM HONEY AS AN ANTI-INFLAMMATORY}

Inflammation is a body defense mechanism against infection, tissue stress, and injury. It works by releasing various inflammatory signals such as cytokines, chemokines, biogenic amines, and eicosanoids which result in multitude changes in various biological processes ranging from vascular responses to adjustments of body temperature [34]. Besides, inflammation also plays a key role in the development of broad-spectrum of complex diseases including autoimmune diseases, metabolic syndrome, neurodegenerative diseases, cancers, and cardiovascular diseases [35]. The mitogen-activated protein kinase (MAPK) and nuclear factor kappa B (NF- $\mathrm{B}$ ) signaling pathways are among critical elements in the inflammatory response that is commonly dysregulated in cancers [36]. NF- $\mathrm{BB}$ signaling has been reported to play a pivotal role in the regulation of tumor angiogenesis and invasiveness, in addition, to confer a protective advantage for cancer cells to withstand apoptosis [37]. Various studies have been undertaken by different groups of researchers to investigate the antiinflammatory properties of Gelam honey. In one study, Gelam honey has been reported to reduce the activation of NF- $\mathrm{KB}$ and MAPK in a dose-dependent manner in pancreatic hamster (HIT-T15) cell line at concentrations of 20,40,60, and $80 \mu \mathrm{g} / \mathrm{mL}$ for $24 \mathrm{~h}$ [38]. Another group of researchers found that HIT-T15 cell line treated with Gelam honey at similar concentrations previously reported by Batumalaie [38] had resulted in under-expression of phosphorylated JNK, IKK- $\beta$, and IRS-1 besides reduced expression of pro-inflammatory cytokines such as tumor necrosis factor alpha (TNF- $\alpha$ ), interleukin (IL)-6, and IL-1 $\beta$ $(P<0.05)$. Taken together, research findings highlighted the potential use of Gelam honey in regulating the inflammation-induced signaling pathways [39]. 
Kassim [40] used an animal model (male Sprague Dawley rats) to assess the inhibitory activity of Gelam honey and its methanolic and acetyl acetate extracts on nitric oxide $(\mathrm{NO})$ and prostaglandin $\mathrm{E}_{2}$ $\left(\mathrm{PGE}_{2}\right)$ in inflammatory tissues. In this study, edema was induced in the non-immune inflammatory and nociceptive model by injecting the rats' paw using $1 \% \mathrm{~g} / \mathrm{mL}$ carrageenan while the immune inflammatory model was subjected to lipopolysaccharide (LPS) injection to study the anti-inflammatory effects of Gelam honey. Their study revealed that Gelam honey, as well as its methanolic and ethyl acetate, extracts significantly reduced the edema $(P<0.05)$ and pain in inflammatory tissues besides exhibiting a potent inhibitory activities against $\mathrm{NO}$ and $\mathrm{PGE}_{2}$ in exudates of paw tissues in both models $(P<0.05)$. Both NO and $\mathrm{PGE}_{2}$ are important mediators of inflammation. Based on their research findings, Gelam honey, and its extracts have been shown to reduce the inflammatory activity by decreasing the main inflammatory signs (inhibition of swelling and pain reduction) and markers of inflammation ( $\mathrm{NO}$ and $\mathrm{PGE}_{2}$ ). They further reported that the presence of major phenolic compounds in the methanolic and acetyl acetate extracts including gallic acid, ellagic acid, caffeic acid, luteolin, chrysin, and quercetin contributed to the anti-inflammatory activity of Gelam honey [40]. Apart from that, Hussein [2] conducted another study to investigate the effect of Gelam honey in inflammation-induced rats by carrageenan. Gelam honey was found to reduce the formation of edema in time- and dose-dependent manner when the treatment was conducted at the concentration of 1 or $2 \mathrm{~g} / \mathrm{kg}$ of body weight $(P<0.05)$ for $1-7$ days. Based on their report, Gelam honey exhibited higher inhibition of edema at $54.23 \%$ and $59.86 \%$, respectively, when administered with Gelam honey at 1 or $2 \mathrm{~g} / \mathrm{kg}$ of body weight in 7 days treatment compared to $26.58 \%$ and $29.11 \%$, as observed on 1 day treatment using the similar doses of Gelam honey. Moreover, they found that oral administration of Gelam honey at 1 or $2 \mathrm{~g} / \mathrm{kg}$ of body weight let to a significant reduction in NO, PGE $2, T N F-\alpha$, and IL-6 levels in plasma and under-expression of inflammatory-related enzymes (inducible nitric oxide synthase [iNOS] and cyclooxygenase $[\mathrm{COX}]-2$ ), pro-inflammatory cytokines (TNF- $\alpha$ and IL-6) genes and proteins in rats' paw tissues. Interestingly, the anti-inflammatory effect of Gelam honey, particularly at a dose of $2 \mathrm{~g} / \mathrm{kg}$ of body weight was found to be comparable to that effect of nonsteroidal anti-inflammatory drug Indomethacin $(10 \mathrm{mg} / \mathrm{kg}$ of body weight), suggesting its potential as natural anti-inflammatory agent to be commercialized in the near future [2].

Recent work from the same group of researchers made another effort to elucidate the anti-inflammatory effect of Gelam honey in carrageenan-induced rat paw inflammation through the NF-kB signaling pathway [41]. This study applied similar doses of Gelam honey ( 1 or $2 \mathrm{~g} / \mathrm{kg}$ of body weight) and treatment period as described from their previous study [2]. They found that increased NF- $\kappa B$ (p65 and $\mathrm{p} 50)$ and $\mathrm{I} \kappa \mathrm{B} \alpha$ gene expressions in inflamed rat paws in response to carrageenan injection were remarkably attenuated $(P<0.05)$ by Gelam honey in day 1 and day 7 models. They also reported that these effects were more pronounced in the treatment with $2 \mathrm{~g} / \mathrm{kg}$ of body weight for 7 days, nearly similar to that effect of the treatment using Indomethacin (10 $\mathrm{mg} / \mathrm{kg}$ of body weight). Moreover, they also focused on the expression of COX-2 and TNF- $\alpha$ in this study. Both proteins are among the central regulators of inflammation $[42,43]$. During inflammation, when the transcription factor NF- $\mathrm{BB}$ was activated, this results in the up-regulation of pro-inflammatory mediator genes expressions including IL-1 $\beta$, IL-6, iNOS, COX-2, and TNF- $\alpha$ [44]. Therefore, inhibiting NF- $\mathrm{KB}$ activation and its translocation into the nucleus besides reducing the release of pro-inflammatory mediators have been the primary focus these days to reduce inflammation [41]. Based on the immunochemistry analyses, carrageenan-induced inflammation group had higher COX-2 expression (80.6\%) before treatment with Gelam honey. Treatment with $2 \mathrm{~g} / \mathrm{kg}$ of body weight with Gelam honey for 7 days resulted in a higher reduction of COX-2 expression (26.29\%) compared to day $1(44.14 \%)$. In a similar way, rats injected with carrageenan demonstrated high TNF- $\alpha$ protein expression $(68.95 \%)$ before treatment with Gelam honey. Their analysis revealed that inflamed rat paws treated with 1 or $2 \mathrm{~g} / \mathrm{kg}$ of body weight for 7 days led to significant reduction in TNF- $\alpha$ protein expression at $29.53 \%$ and $22.80 \%$, respectively, compared to day 1 treatment $(53.75 \%$ and $30.11 \%$ ). Overall, they postulated that the inhibitory mechanism of Gelam honey happened through the inactivation of NF- $\mathrm{BB}$, which subsequently blocks the I $\kappa \mathrm{B} \alpha$ degradation and nuclear translocation of NF- $\kappa B$ subunits, $\mathrm{p} 65$ and $\mathrm{p} 50$ thereby inhibit NF- $\kappa \mathrm{B}$ binding to its target DNA. As a result, the transcriptional activity of several numbers of pro-inflammatory genes including COX-2, TNF- $\alpha$, IL- 6 , and iNOS were inhibited [41].

An independent study by Kassim [45] evaluated the anti-inflammatory effect of Gelam honey using rats with LPS-induced endotoxemia. LPS is the main component of bacterial outer membrane found in Gramnegative bacteria that serve as a physical barrier to confer protective advantage for the bacteria from the surroundings. It also plays a pivotal role within the immune system as a marker to detect the invasion of pathogenic bacteria, development of inflammatory response and has the potential to induce cytotoxic shock [46]. In this study, endotoxemia induced-rats received $60 \mathrm{mg} / \mathrm{kg}, 300 \mathrm{mg} / \mathrm{kg}$, and $600 \mathrm{mg} / \mathrm{kg}$ dose of a solution containing Gelam honey diluted in $1 \mathrm{~mL}$ saline while the control group only received $1 \mathrm{~mL}$ saline injected intravenously through the tail vein. Serum levels of TNF- $\alpha$, IL-1, IL-6, IL-10, NO, and heme oxygenase-1 (HO-1) were examined after $4 \mathrm{~h}$ treatment using an enzyme-linked immunosorbent assay (ELISA). Based on the results, Gelam honey was reported to cause a significant reduction in the cytokine TNF- $\alpha$, IL-1, IL-6, IL-10, and NO levels while increasing the HO-1 level following $4 \mathrm{~h}$ treatment, thereby protecting rats from endotoxemia [45]. HO-1 has been shown to improve survival in lethal endotoxemia in animal models [47]. Ergo, inhibiting the cytokines, $\mathrm{NO}$, and high mobility group protein $\mathrm{B} 1$ release while stimulating the expression of HO-1 in response to LPS serve as an important protection strategy against endotoxemia $[45,47]$.

Periodontitis, defined by gingival inflammation, periodontal pocket formation and the development of bacterial plaque which consequently lead to alveolar bone destruction and tooth loss is among the major chronic inflammatory diseases in adults across the globe [48]. Since there has been increasing interest toward the use of natural products in the dentistry field, previous work by Aziz [49] looked for anti-inflammatory effects of Gelam honey in a periodontitis-induced Sprague-Dawley rat model. This study was conducted by assigning the rats into 4 distinct groups; NLS (control treated with saline), NLH (control treated with Gelam honey and $3 \mathrm{~g} / \mathrm{kg}$ of body weight), LS (periodontitis treated with saline), and LH (periodontitis treated with Gelam honey and $3 \mathrm{~g} / \mathrm{kg}$ of body weight). Analysis revealed that Gelam honey caused a significant reduction in IL-1 $\beta$ levels in periodontitis induced rats with a total reduction recorded at $21.26 \%$ and $81.27 \%$, respectively, in plasma and tissue samples when measured by ELISA and immunohistochemical staining. Thus, the results clearly highlighted the effectiveness of Gelam honey in alleviating the increased level of inflammatory mediator in periodontal disease [49]. 


\section{GELAM HONEY AS A WOUND HEALING}

Wound healing is a multi-step processes consisting of three sequential stages known as inflammation, proliferation, and maturation [50]. Honey has long being applied in the treatment of wound since the ancient times [51]. Emerging evidence from the clinical trials has been supporting the effectiveness of honey to treat a variety of acute and chronic wounds. Wijesinghe [52] performed a randomized controlled trial to compare the efficiency of honey than other dressings, particularly silver sulfadiazine (SSD)-impregnated gauze involving 624 subjects from 8 independent studies. According to the result, they found that honey was associated with improved rate of healing (odds ratio, odds ratio $6.1,95 \%$ confidence interval: 3.7-9.9) at 15 days, thereby suggesting its superiority compared to other dressings [52]. Another study which aimed to compare the effectiveness of honey dressing than the ethoxy-aminoacridine plus nitrofurazone dressing found that patients who received honey dressing had a remarkably better pressure ulcer scale for healing scores than those treated with ethoxy-aminoacridine plus nitrofurazone dressing at 5-weeks [53].

The wound healing potential of Gelam honey has been explored by a number of previous studies. Aljady and collaborators evaluated the effectiveness of Gelam honey in the process of wound healing by looking on the biophysical and biochemical changes in SpragueDawley rat model. Wound healing capacity of Gelam honey was assessed by tracing the wounded areas onto a transparent plastic grid while calculating those areas with specific counting formula. They found that best oral and topical administration of Gelam honey on healing would be at $1.5-2.0 \mathrm{~mL}$ and $0.1-0.15 \mathrm{~mL} / \mathrm{cm}^{2}$ concentration, respectively. Besides, high DNA content following Gelam honey treatment measured on day $4(P<0.05)$, days 8,12 , and $16(P<0.01)$ served as an indicator for increased cell proliferation in the newly formed granulation tissue. Moreover, increased collagen content on days 8 and $12(P<0.05)$ and day $16(P<0.01)$ after honey treatment in the granulation tissue was speculated to be due to the presence of high levels of glycine, methionine, arginine, and proline that play critical roles in collagen formation and deposition. In addition, they reported that increased level of uronic acid on days 4,8 , and $12(P<0.01)$, and days $16(P<0.05)$, and hexosamine on days 4 , 12 , and $16(P<0.05)$, and day $8(P<0.01)$ compared to control was indicative of the synthesis of glycosaminoglycans, the first components of extracellular matrix to be synthesized during wound healing and act as a template for the deposition of collagen and elastin. Besides, increased percentage of wound contraction rate and serum albumin levels were indicative of accelerated wound healing conferred by Gelam honey [50].

Tensile strength, described as the breaking strength of a material divided by its cross-sectional area is recognized as an ideal physiologic measure to evaluate a wound's ability to resist tension [54]. Besides, it serves as an important parameter which indicates the subdermal organization of the collagen fibers in the newly deposited collagen $[55,56]$. Rozaini [56] made a comparative analysis to analyze the tensile strength of burn wound healing in Sprague-Dawley rats treated with Gelam and Nenas honey. The rats were given both honeys at a dose of $0.5 \mathrm{~mL} 2$ times on a daily basis while the control group did not receive any treatment. It has been found that Gelam honey-treated group exhibited higher values of tensile strength $(\mathrm{MPa})$ at days 3 (0.93 vs. 0.81 ), days 7 (1.55 vs. 1.35), days 14 (1.71 vs. 1.47 ), days 21 (2.47 vs. 1.97 ), and days 28 (2.80 vs. 2.08 ) post-injury than the control group. Although Nenas honey had higher tensile strength values at days
3 (0.95 vs. 0.81$)$, days 14 (2.40 vs. 1.47$)$, days 21 (2.61 vs. 1.97), and days 28 (3.95 vs. 2.08) compared to control and Gelam honeytreated groups, the effect was comparable in both honeys in terms of augmenting the process of dermal wound healing [57]. Subsequent study undertaken by similar group of researchers to identify the wound healing properties of both honeys on the histological basis found that Gelam honey-treated group had lower inflammatory cells, particularly neutrophils on days 7 (26.50 vs. 40.90$)$, days 14 (6.86 vs. 47.06), days 21 (3.93 vs. 60.63), and days 28 ( 0.4 vs. 51.43), and higher fibroblasts (44.56, 56.86, 68.26, 49.23, and 27.30, respectively, on days 3, $7,14,21$, and 28) and endothelial cells $(5.76,6.90,6.56,7.20$, and 5.40 , respectively, on days $3,7,14,21$, and 28) compared to control group. Overall, they concluded that these results were indicative of progressive wound healing process conferred by Gelam honey [57].

In the following year, these researchers conducted another study to evaluate the macroscopic changes of burn wound healing in response to the treatment with various types of honey (Gelam, coconut, Nenas, Manuka, and Durian). Data showed that Gelam honey had a higher percentage of wound contraction, measured longitudinally post-burned in days 7 (5.60 vs. 1.30), days 14 (33.10 vs. 6.75), days 21 (56.10 vs. 19.41), and days 28 (83.86 vs. 46.48) compared to control. Manuka honey also exhibited a similar effect, when the percentage of wound contraction was recorded at 6.05, 32.86, 52.66, and 87.20, respectively, on similar treatment periods. Moreover, the percentage of wound contraction when measured transversely in Gelam honey-treated group showed a progression in a timedependent manner, with the highest value recorded at days 28 postburned ( 87.50 vs. 50.21) compared to control. Besides, Manuka honey also showed highest percentage of wound contraction at days 28 (90.71 vs. 50.21) compared to control and Gelam honey-treated group, therefore, suggesting that topical application of Manuka and Gelam honeys are highly effective to accelerate the wound healing process as observed from the increased rate of wound contraction and gross appearances [58].

Ongoing effort to study the wound healing activity of Gelam honey has led to the development of honey hydrogel dressing to improve the rate of wound healing. The experiment was conducted in vivo using Sprague-Dawley rats. The hydrogel dressing which comprised a mixture of $15 \%$ polyvinyl pyrrolidone (PVP) (Kollidon 90), 1\% protein free agar (Oxoid) solution, 1\% polyethylene glycol (PEG), and Gelam honey at $6 \%, 8 \%, 10 \%$, and $15 \%$ concentration has been found to stimulate the rate of burn wound healing as indicated by the rate of wound contraction at $8.58 \%$ and $5.6 \%$, higher than the treatment with SSD cream $(3.43 \%$ and $3.41 \%)$ and untreated control group $(9.5 \%$ and $1.3 \%)$ at days 7 when measured transversely and longitudinally. The rate of burn wound healing in Gelam honey hydrogel dressing was reported to progress over time, as the highest rate of wound contraction was recorded at $87.50 \%$ (transverse) and $83.86 \%$ (longitudinal), higher than the treatment with SSD cream (69.60\% transversely and 63\% longitudinally) and control $(50.21 \%$ and $46.48 \%$ transversely and longitudinally). In addition to that, microscopic observation showed that there was a significant increase in the rate of dermal repair in the wounded area that was treated with Gelam honey. Histological analysis further indicates that Gelam honey attenuates inflammatory reaction, and caused a progressive epithelial regeneration in the wounded area compared to control. Furthermore, most ideal concentration of Gelam honey to be incorporated into the hydrogel dressing was found to be at $6 \%$, as it was reported to be easily peeled from mold, transparent and completely cross-linked than $8 \%, 10 \%$, and $15 \%$ honey dressings following irradiation at 25 
kGy. Results from this study clearly suggested the potential use of Gelam honey incorporation into the hydrogel as wound dressing with high healing capability than the commercialized SSD-cream treated wound [59].

Other study investigated the wound healing efficacy of Gelam honey by incorporating $6 \%(\mathrm{v} / \mathrm{v})$ Gelam honey into the hydrogel dressing consisted of $15 \%(\mathrm{w} / \mathrm{v})$ PVP, 1\% (w/v) protein free agar solution, and $1 \%(\mathrm{v} / \mathrm{v})$ PEG. They found that Gelam honey-based hydrogel dressing increased the rate of burn wound healing as observed by a higher reduction in wound size at $81.78 \%$ and $91.27 \%$, respectively, after 21 and 28 days post-burn $(P<0.05)$. The microscopic analysis had indicated a significant progression in dermal repair besides higher re-epithelialization process in the wounded area treated with Gelam honey as compared to other groups. Besides, they also reported a significant reduction in the inflammatory response in Gelam honeytreated group at days 7 post-burned $(P<0.05)$. Moreover, molecular analysis revealed that treatment with Gelam honey at the wounded area resulted in significant reductions in the expression of proinflammatory cytokines (IL-1 $\alpha$, IL-1 $\beta$, and IL-6) involved in wound healing, as higher expression of these pro-inflammatory mediators in burn wounds might impair the wound healing process [60]. The effectiveness of Gelam honey as a potent agent of wound healing was further explored by another group of researchers from the University of Malaya, Kuala Lumpur in male adult Sprague-Dawley rats. The rats were assigned into four different groups; the untreated control group did not receive any treatment, positive control group received intrasite gel consisted of a mixture of modified carboxymethyl cellulose polymer, propylene glycol and water, and negative control group was given topical treatment with normal saline while the experimental group received the topical treatment with Gelam honey. Results showed that Gelam honey-treated group had lower healing time (mean 13.17 days vs. 16.67 days vs. 15.83 days) compared to untreated and saline groups, respectively. The healing time also was found to be comparable with the effect of intrasite gel that serves as positive control (mean 13.17 and 13 days, respectively). Macroscopic and histological assessment showed that Gelam honey accelerated the process of wound healing compared to other groups. This effect was said to be attributed to the presence of $\mathrm{H}_{2} \mathrm{O}_{2}, \mathrm{H}_{2} \mathrm{O}_{2}$ in addition to its nutritional properties that confers appropriate environmental conditions to promote the healing process. The percentage of wound contraction in Gelam honey-treated group in addition to the group that receives treatment with intrasite gel was also found to be higher than the untreated and saline groups, further supports its potential as natural wound healing agent [61].

\section{CONCLUSIONS}

Researches related to Gelam honey showed a positive pathway in developed more effective's therapy in preventing or treating many diseases. These putative effects of Gelam honey could lead the society toward better and healthy life. The demand of honey usage in our life still not at a critical level and therefore more information needs to be gather on Gelam honey which is not yet discovered.

\section{ACKNOWLEDGMENTS}

The authors would like to thank the Faculty of Bioresources and Food Industry, Universiti Sultan Zainal Abidin, and the School of Fundamental Science, Universiti Malaysia Terengganu for the technical and financial support of the project, and to the Ministry of Higher Education Malaysia for the scholarship support.

\section{REFERENCES}

1. Hussein SZ, Yusoff KM, Makpol S, Yusof YA. Antioxidant capacities and total phenolic contents increase with gamma irradiation in two types of Malaysian honey. Molecules 2011;16:6378-95.

2. Hussein SZ, Mohd Yusoff K, Makpol S, Mohd Yusof YA. Gelam honey inhibits the production of proinflammatory, mediators NO, PGE(2), TNF- $\alpha$, and IL-6 in carrageenan-induced acute paw edema in rats. Evid Based Complement Alternat Med 2012;2012:109636.

3. Moniruzzaman M, Khalil MI, Sulaiman SA, Gan SH. Physicochemical and antioxidant properties of Malaysian honeys produced by Apis cerana, Apis dorsata and Apis mellifera. BMC Complement Altern Med 2013;13:43.

4. Liu J. Pharmacology of oleanolic acid and ursolic acid. J Ethnopharmacol 1995;49:57-68.

5. Wolter F, Clausnitzer A, Akoglu B, Stein J. Piceatannol, a natural analog of resveratrol, inhibits progression through the $\mathrm{S}$ phase of the cell cycle in colorectal cancer cell lines. J Nutr 2002;132:298-302.

6. Saravanan R, Pugalendi V. Impact of ursolic acid on chronic ethanolinduced oxidative stress in the rat heart. Pharmacol Rep 2006;58:41-7.

7. Monzon R. Traditional medicine in the treatment of parasitic diseases in the Philippines. Southeast Asian J Trop Med Public Health 1995;26:421-8.

8. Israili $\mathrm{ZH}$. Antimicrobial properties of honey. Am J Ther 2014;21:304-23.

9. Mandal MD, Mandal S. Honey: Its medicinal property and antibacterial activity. Asian Pac J Trop Biomed 2011;1:154-60.

10. Zainol MI, Mohd Yusoff K, Mohd Yusof MY. Antibacterial activity of selected malaysian honey. BMC Complement Altern Med 2013;13:129.

11. Bottone EJ. Bacillus cereus, a volatile human pathogen. Clin Microbiol Rev 2010;23:382-98.

12. Tong SY, Davis JS, Eichenberger E, Holland TL, Fowler VG Jr., Staphylococcus aureus infections: Epidemiology, pathophysiology, clinical manifestations, and management. Clin Microbiol Rev 2015;28:603-61.

13. Ng WJ, Ken KW, Kumar RV, Gunasagaran H, Chandramogan V, Lee YY, et al. In-vitro screening of malaysian honey from different floral sources for antibacterial activity on human pathogenic bacteria. Afr J Tradit Complement Altern Med 2014;11:315-8.

14. Ng WJ, Lim MS. Anti-staphylococcal activity of melaleuca honey. Southeast Asian J Trop Med Public Health 2015;46:472-9.

15. Mohamed JA, Huang DB. Biofilm formation by Enterococci. J Med Microbiol 2007;56:1581-8.

16. Römling $U$, Balsalobre C. Biofilm infections, their resilience to therapy and innovative treatment strategies. J Intern Med 2012;272:541-61.

17. Paganelli FL, Willems RJ, Jansen P, Hendrickx A, Zhang X, Bonten MJ, et al. Enterococcus faecium biofilm formation: Identification of major autolysin atlAEfm, associated acm surface localization, and atlAEfm-independent extracellular DNA release. MBio 2013;4:e0154.

18. Lee JH, Park JH, Kim JA, Neupane GP, Cho MH, Lee CS, et al. Low concentrations of honey reduce biofilm formation, quorum sensing, and virulence in escherichia coli O157:H7. Biofouling 2011;27:1095-104.

19. Ng WJ, Lim KY, Chong JY, Low KL. In vitro screening of honey against Enterococcus spp. Biofilm. J Med Bioeng 2014;3:23-8.

20. Aljadi AM, Yusoff K. Isolation and identification of phenolic acids in Malaysian honey with antibacterial properties. Turk J Med Sci 2003;33:229-36.

21. Ahmed S, Othman NH. Honey as a potential natural anticancer agent: A review of its mechanisms. Evid Based Complement Alternat Med 2013;2013:829070.

22. Premratanachai P, Chanchao C. Review of the anticancer activities of 
bee products. Asian Pac J Trop Biomed 2014;4:337-44.

23. Abu MN, Salleh MA, Eshak Z, Hasan MH, Hassan HF, Ismail WI. Anti-proliferative effect of Tinaspora crispa (L.) Hook. F. and Thompson and Gelam (Melaleuca sp.) Honey on Several Cancer Cell Lines. Paper Presented at the Business, Engineering and Industrial Applications (ISBEIA), 2011 IEEE Symposium on.

24. Jubri Z, Narayanan NN, Karim NA, Ngah WZ. Antiproliferative activity and apoptosis induction by Gelam honey on liver cancer cell line. Int J Appl Sci Technol 2012;2:135-41.

25. Fadhli MM, Noorfathiah I, Hana MN, Ashraf MM, Zolkapli E, Mizaton $\mathrm{H}$, et al. Gelam (Melaleuca sp.) Honey Demonstrates Antiproliferative Effect on Colon Cancer Cell Lines (HCT116). Paper Presented at the Business, Engineering and Industrial Applications (ISBEIA), 2012 IEEE Symposium on; 2012.

26. Wen CT, Hussein SZ, Abdullah S, Karim NA, Makpol S, Mohd Yusof YA, et al. Gelam and nenas honeys inhibit proliferation of HT 29 colon cancer cells by inducing DNA damage and apoptosis while suppressing inflammation. Asian Pac J Cancer Prev 2012;13:1605-10.

27. de Kok TM, van Breda SG, Manson MM. Mechanisms of combined action of different chemopreventive dietary compounds: A review. Eur J Nutr 2008;47 Suppl 2:51-9.

28. Hakim L, Alias E, Makpol S, Ngah WZ, Morad NA, Yusof YA, et al. Gelam honey and ginger potentiate the anti cancer effect of 5-FU against HCT 116 colorectal cancer cells. Asian Pac J Cancer Prev 2014;15:4651-7.

29. Longley DB, Harkin DP, Johnston PG 5-fluorouracil: Mechanisms of action and clinical strategies. Nat Rev Cancer 2003;3:330-8.

30. Tahir AA, Sani NF, Murad NA, Makpol S, Ngah WZ, Yusof YA. Combined ginger extract and Gelam honey modulate Ras/ERK and PI3K/AKT pathway genes in colon cancer HT29 cells. Nutr J 2015;14:31.

31. Wee LH, Morad NA, Aan GJ, Makpol S, Wan Ngah WZ, Mohd Yusof YA. Mechanism of chemoprevention against colon cancer cells using combined gelam honey and ginger extract via mTOR and wnt/beta-catenin pathways. Asian Pac J Cancer Prev 2015;16:6549-56.

32. Mashima T, Taneda Y, Jang MK, Mizutani A, Muramatsu Y, Yoshida H, et al. MTOR signaling mediates resistance to tankyrase inhibitors in wnt-driven colorectal cancer. Oncotarget 2017;8:47902-15.

33. Wang XW, Zhang YJ. Targeting mTOR network in colorectal cancer therapy. World J Gastroenterol 2014;20:4178-88.

34. Kotas ME, Medzhitov R. Homeostasis, inflammation, and disease susceptibility. Cell 2015;160:816-27.

35. Murakami M, Hirano T. The molecular mechanisms of chronic inflammation development. Front Immunol 2012;3:323.

36. Porcza LM, Simms C, Chopra M. Honey and cancer: Current status and future directions. Diseases 2016;4.

37. Fan Y, Mao R, Yang J. NF-kappaB and STAT3 signaling pathways collaboratively link inflammation to cancer. Protein Cell 2013;4:176-85.

38. Batumalaie K, Zaman Safi S, Mohd Yusof K, Shah Ismail I, Devi Sekaran S, Qvist R, et al. Effect of gelam honey on the oxidative stress-induced signaling pathways in pancreatic hamster cells. Int J Endocrinol 2013;2013:367312.

39. Safi SZ, Batumalaie K, Qvist R, Mohd Yusof K, Ismail IS. Gelam honey attenuates the oxidative stress-induced inflammatory pathways in pancreatic hamster cells. Evid Based Complement Alternat Med 2016;2016:5843615.

40. Kassim M, Achoui M, Mansor M, Yusoff KM. The inhibitory effects of gelam honey and its extracts on nitric oxide and prostaglandin E(2) in inflammatory tissues. Fitoterapia 2010;81:1196-201.

41. Hussein SZ, Yusoff KM, Makpol S, Yusof YA. Gelam honey attenuates carrageenan-induced rat paw inflammation via NFkappaB pathway. PLoS One 2013;8:E72365.

42. Chen C. COX-2's new role in inflammation. Nat Chem Biol
2010;6:401-2.

43. Esposito E, Cuzzocrea S. TNF-alpha as a therapeutic target in inflammatory diseases, ischemia-reperfusion injury and trauma. Curr Med Chem 2009; 16:3152-67.

44. Ghosh S, May MJ, Kopp EB. NF-kappa B and rel proteins: Evolutionarily conserved mediators of immune responses. Annu Rev Immunol 1998;16:225-60.

45. Kassim M, Yusoff KM, Ong G, Sekaran S, Yusof MY, Mansor M, et al. Gelam honey inhibits lipopolysaccharide-induced endotoxemia in rats through the induction of heme oxygenase- 1 and the inhibition of cytokines, nitric oxide, and high-mobility group protein B1. Fitoterapia 2012;83:1054-9.

46. Rosenfeld Y, Shai Y. Lipopolysaccharide (Endotoxin)-host defense antibacterial peptides interactions: Role in bacterial resistance and prevention of sepsis. Biochim Biophys Acta 2006;1758:1513-22.

47. Tsoyi K, Lee TY, Lee YS, Kim HJ, Seo HG, Lee JH, et al. Hemeoxygenase-1 induction and carbon monoxide-releasing molecule inhibit lipopolysaccharide (LPS)-induced high-mobility group box 1 release in vitro and improve survival of mice in LPS- and cecal ligation and puncture-induced sepsis model in vivo. Mol Pharmacol 2009;76:173-82.

48. Hamzah N, Aziz SA, Fauzi AR, Yusof YA, Razali M, Ibrahim N, et al. Effects of gelam honey (Melaleuca cajuputi) on alveolar bone loss in experimental periodontitis. J Dent Surg 2014;8. DOI: 10.1155/2014/907970.

49. Aziz SA, Hamzah N, Fauzi AR, Yusof YA, Ibrahim N, Rahman MA, et al. The effect of gelam (Melaleuca cajuputi) honey on inflammatory mediators in periodontitis-induced sprague-dawley rats. Int J Appl Res Nat Prod 2014;7:7-16.

50. Aljady A, Kamaruddin M, Jamal A. Biochemical study on the efficacy of Malaysian honey on inflicted wounds: An animal model. Med J Islamic Acad Sci 2000;13:125-32.

51. Molan P, Rhodes T. Honey: A Biologic wound dressing. Wounds 2015;27:141-51.

52. Wijesinghe M, Weatherall M, Perrin K, Beasley R. Honey in the treatment of burns: A systematic review and meta-analysis of its efficacy. N Z Med J 2009;122:47-60.

53. Yapucu Güneş U, Eşer I. Effectiveness of a honey dressing for healing pressure ulcers. J Wound Ostomy Continence Nurs 2007;34:184-90.

54. Ireton JE, Unger JG, Rohrich RJ. The role of wound healing and its everyday application in plastic surgery: A practical perspective and systematic review. Plast Reconstr Surg Glob Open 2013;1:e10-9.

55. Jimenez PA, Rampy MA. Keratinocyte growth factor- 2 accelerates wound healing in incisional wounds. J Surg Res 1999;81:238-42.

56. Rozaini MZ, Zuki A, Noordin M, Norimah Y, Hakim AN. Tensile Strength Evaluation on Burns Wound Healing Treated With Nenas (Ananas comosus spp.) and Gelam (Melaleuca spp.) honey, 2004a; Paper presented at the Animal health: A breakpoint in economic development? The $11^{\text {th }}$ International Conference of the Association of Institutions for Tropical Veterinary Medicine and $16^{\text {th }}$ Veterinary Association Malaysia Congress. Petaling Jaya, Malaysia; 2004.

57. Rozaini MZ, Zuki AB, Noordin M, Norimah Y, Hakim AN. Histological Evaluation on Burns Wound Healing Treated With Nenas (Ananas comosus spp.) and Gelam (Melaleuca spp.) honey, 2004b Paper Presented at the Animal health: A breakpoint in economic development? The $11^{\text {th }}$ International Conference of the Association of Institutions for Tropical Veterinary Medicine and $16^{\text {th }}$ Veterinary Association Malaysia Congress. Petaling Jaya, Malaysia; 2004.

58. Rozaini MZ, Zuki AB, Noordin MM, Norimah Y, Hakim AN. Macroscopie evaluation of burn wounds healing progress treated with different honey. Pak J Biol Sci 2005;8:672-8.

59. Yusof N, Hafiza AA, Zohdi RM, Bakar MZ. Development of honey 
hydrogel dressing for enhanced wound healing. Radiat Physics Chem 2007;76:1767-70.

60. Zohdi RM, Bakar Zakaria ZA, Yusof N, Mustapha NM, Abdullah MN. Gelam (Melaleuca spp.) honey-based hydrogel as burn wound dressing. Evid Based Complement Alternat Med 2012;2012:843025.

61. Tan MK, Hasan Adli DS, Tumiran MA, Abdulla MA, Yusoff KM.
The efficacy of gelam honey dressing towards excisional wound healing. Evid Based Complement Alternat Med 2012;2012:805932.

How to cite this article:

Johari SATT, Hashim F, Ismail WIW, Ali AM. A review on biological activities of Gelam honey. J App Biol Biotech. 2019;7(01):71-78.

DOI: $10.7324 / J A B B .2019 .70113$ 